American Journal of Pharmaceutical Education 2019; 83 (1) Article 7051.

\title{
COMMENTARY
}

\section{Trends in the Pharmacist Workforce and Pharmacy Education}

\author{
Lisa Lebovitz, JD, Natalie D. Eddington, $\mathrm{PhD}$ \\ University of Maryland School of Pharmacy, Baltimore, Maryland \\ Submitted March 5, 2018; accepted August 19, 2018; published February 2019.
}

\begin{abstract}
This commentary is an observation of longitudinal trends in national data on the pharmacist workforce and pharmacy education. Data indicate seismic shifts in supply and demand, from critical shortage to imminent oversupply. The change in the profession to employing more patient-care focused jobs has been observed as slow and minimal, although academia has focused on the clinical training and rapidly increased enrollments. Pharmacy is on the brink of transforming the profession, but several important changes are still required to alter the current trajectories of supply and demand. Pharmacy schools, associations, and employers must devote all energies to immediate and significant actions that tip the balance in favor of pharmacists of the future.
\end{abstract}

Keywords: workforce, employment, trends

\section{INTRODUCTION}

There is no topic more urgent at this moment for every pharmacist in the US than what is happening and what needs to happen in the pharmacy profession and pharmacy education. The supply of pharmacists in the workforce is rapidly exceeding demand as retail chains are consolidating and reducing labor costs, while pharmacy schools continue to open and expand. ${ }^{1-3}$ Someone should do something, but who bears responsibility to act? Pharmacy associations have been calling for transformation of the profession by advocating for provider status and prioritizing interprofessional education and practice, but have been focusing their more visible activities on attracting applicants to pharmacy schools. Accreditation standards have driven educational changes to ensure that pharmacy students are highly trained and prepared for this transformation, but moving programs beyond the needs of the current job market that graduates are entering. Thought leaders have been observing marketplace trends and urging pharmacy colleges and schools to produce a product of value; that is, an appropriate number of competent entry-level practitioners trained to fill the positions that employers have available. Pharmacy colleges and schools have responded to the accreditation requirements, but generally seem to be overlooking the supply and demand data. Employers, particularly retail pharmacies where the majority of pharmacy graduates are employed, ${ }^{3}$

Corresponding Author: Lisa Lebovitz, University of Maryland School of Pharmacy, 20 North Pine St., PH S303, Baltimore, MD 21201. Tel: 410-706-3457. E-mail:

llebovitz@rx.umaryland.edu are singularly focused on their business model and little if any "transformation" is evident there.

However, the profession is closer than ever to achieving provider status, ${ }^{4}$ and now is the time for pharmacy associations to press for these critical legislative changes to expand pharmacists' roles. Pharmacy employers know that new graduates are entering the job market prepared with the essential knowledge, skills, abilities, and attitudes to function as the drug experts in collaborative health care models, and business models must change to capitalize on the value of pharmacists' patient care training. At the same time, pharmacy schools must limit enrollments to highly qualified applicants to ensure that all future graduates can secure full-time positions.

\section{Employment Projections are Changing Exponentially}

Longitudinal trends in national data on the pharmacist workforce indicate seismic shifts in supply and demand in recent years. The Bureau of Labor Statistics (BLS) is part of the US Department of Labor, and its mission is to measure and analyze economic activity and changes in the labor market to inform public and private decision-making. ${ }^{5}$ Twice per year the BLS estimates employment and wages in 800 occupations, and then uses the data to develop and adjust 10-year occupational projections every two years. ${ }^{6}$ Trends in projected growth of the pharmacist profession have rapidly shifted from severe shortage to imminent surplus. In 2002, BLS projected 10-year growth of a robust $30.1 \%$ from 230,000 to 299,000 pharmacists by 2012 , more than double the national employment growth projection of $14.8 \% .{ }^{1}$ Actual growth of the pharmacist profession was $20.5 \%$ between 2002 and 2012. ${ }^{7}$ In 2006, BLS projected a 10-year 


\section{American Journal of Pharmaceutical Education 2019; 83 (1) Article 7051.}

growth of $21.7 \%$ from 243,000 to 296,000 pharmacists by 2016, again more than double the national employment growth projection of $10.4 \% .{ }^{8}$ Actual growth of the pharmacist profession was a healthy $23.4 \%$ between 2006 and 2016. In 2012, BLS projected 10-year growth of $14.5 \%$ from 286,400 to 327,800 pharmacists by $2022,{ }^{9}$ still $35 \%$ greater than the national employment growth projection of $10.8 \%{ }^{7}$ In 2016, BLS projected a 10-year growth of 5.6\% from 312,500 to 330,100 pharmacists by $2026,25 \%$ below the national employment growth projection of $7.4 \% .^{3}$

The BLS methodology for projected occupational employment includes both qualitative and quantitative resources to identify any structural shifts in the occupation. ${ }^{10}$ For the 2016 projection, BLS noted that employment outlook for the pharmacist profession may be positively affected by aging baby boomers, higher rates of chronic diseases, and scientific advances in drug development; negative impact may be caused by decreases in traditional retail pharmacy settings, and growth in the number of pharmacy schools creating more competition for jobs. ${ }^{3}$

Projections of declining growth in the pharmacist profession are also reflected in the Pharmacist Demand Indicator (PDI) (formerly the Aggregate Demand Index, a monthly survey of a confidential panel of pharmacist employers representing the major geographic and practice sectors of pharmacy practice in the US, regarding perceived difficulty in filling open positions or whether demand was less than supply). ${ }^{11}$ The Pharmacy Workforce Center (PWC) (formerly known as the Pharmacy Manpower Project, Inc.) provides research and analysis specific to the pharmacy workforce ${ }^{12}$ including conducting the PDI, a quarterly national survey that collects perceptions of the demand for pharmacists among a panel of individuals that hire pharmacists on a regular basis. ${ }^{13}$ The PDI asks respondents to rate on a scale from 1 to 5 the perceived shortages, balance, and excess of pharmacists in the workforce. A score of 1 indicates demand is much less than supply, 2 indicates moderate oversupply, 3 indicates balanced supply and demand, 4 indicates moderate demand, and 5 indicates high demand and short supply. ${ }^{14}$ Although modifications were made in the collection method when ADI changed to the PDI in 2016, ${ }^{15}$ the national perceptions align with BLS projections and indicate a slow and steady decline in demand over time: 3.83 in 2006, 3.78 in 2008, 3.09 in 2010, 2.80 in 2012, 2.92 in $2014,3.00$ in $2016,{ }^{16}$ and 2.98 in the fourth quarter of $2017 .{ }^{17}$

\section{Declines in Demand Cannot Be Overlooked}

The PWC also catalogs national pharmacist workforce surveys that have been conducted every 4-5 years since $2000 .^{18}$ The 2000 report noted that demand was much greater than supply, leading to "drastic" wage increases and signing bonuses. ${ }^{19}$ The 2004 report reiterated an increase in demand for pharmacists due to higher prescription volume and maintained a positive outlook for the profession. However, the report also mentioned factors tempering demand such as lack of growth in the number of retail pharmacies, increasing number of pharmacy schools and graduates, expansion of technician staffing ratios, and the use of dispensing technology. ${ }^{20}$ The 2009 report was distinctly less optimistic due to the economic downturn, having found that one-third of hospitals and chains restructured employment to save on labor costs. Notably, the increasing rate of part-time employment of pharmacists was identified as an important factor to observe as the economy rebounds and the number of pharmacy graduates continues to increase. ${ }^{21}$ The post-recession 2014 report identified a continued and increased trend in labor reductions or workforce adjustments compared to the 2009 report. Restructuring of pharmacist work schedules to save on labor costs was reported by $35 \%$ of pharmacist respondents (compared to 26\% in 2009); 17\% reported mandatory reductions in pharmacist hours (13\% in 2009), $9 \%$ reported pharmacist layoffs (6\% in 2009), and 6\% reported early retirement incentives for pharmacists (4\% in 2009). ${ }^{22}$

In 2007, Knapp and Cultice revised workforce estimates from 2000 and projected an unexpectedly greater pharmacist supply over time, finding that pharmacists were remaining in the workforce longer and pharmacy education was continuing to swell. ${ }^{23}$ While delayed retirements accounted for nearly $60 \%$ of the increased supply, the overall pharmacist workforce was projected to become younger by four years due to "unabated" educational expansion. Of note, at the time of this revision project in 2007, there were 9,800 graduates from 100 pharmacy schools, and in 2016 there were 14,556 graduates from 128 pharmacy schools. Knapp and Cultice projected a total of 304,986 pharmacists in the workforce by 2020; however, that number was exceeded four years early as reported by the 2016 BLS occupational statistic.

Although some may hope that the current oversupply problem will be resolved by pending retirements, the younger workforce projected by Knapp and Cultice 10 years ago is evident in the 2017 report by the National Association of Boards of Pharmacy (NABP) for the Pharmacy Workforce Center, in which NABP summarized its e-profile aggregate data. ${ }^{24}$ E-profiles are maintained by NABP for the purpose of CPE Monitor data collection. ${ }^{25}$ Notable findings include: $73 \%$ of US-licensed pharmacists that reported a birthdate $(n=327,555)$ were born in 1960 or later; ie, age 57 or younger. Of those reporting 


\section{American Journal of Pharmaceutical Education 2019; 83 (1) Article 7051.}

education $(n=215,820), 68 \%$ held a PharmD degree and $86 \%$ indicated graduating after January 1, 1990.

\section{Oversupply Will Suffer Financial Impacts}

In terms of salary, pharmacists are currently among the highest paid health care practitioners after physicians and surgeons, dentists, and podiatrists. ${ }^{26}$ The BLS 2016 10 -year projected growth for these professions range from $10 \%$ (podiatrists), ${ }^{27}$ to $13 \%$ (physicians and surgeons), ${ }^{28}$ to $19 \%$ (dentists), ${ }^{29}$ compared to pharmacists' $5.6 \% .^{30}$ Much greater employment growth is projected for other health care professions of comparable education and training: physician assistants (37\%) and nurse practitioners (36\%), ${ }^{31}$ and it is important to observe that median salaries for these high-growth professions are 20\%-30\% lower than pharmacists. As projected pharmacist demand decreases, so does salary growth. Over the last 10 years, the year-to-year increase in pharmacists' median annual salary has shrunk from 3\% to 6\% between 2007 and 2011 to $1 \%-2 \%$ between 2012 and 2016, without adjusting for inflation. ${ }^{32}$ Another notable finding reported by BLS is that although most pharmacists work full-time, about $20 \%$ ( 1 in 5) worked part-time in $2016^{33}$

In 2012, when the BLS was projecting 14.5\% growth in employment for pharmacists, nearly 8,700 graduates of 110 colleges and schools of pharmacy completed the American Association of Colleges of Pharmacy (AACP) Graduating Student Survey. That year, respondents reported that the average amount borrowed to finance their PharmD education was $\$ 123,063$ ( $\$ 103,829$ for graduates of public institutions and $\$ 142,849$ for graduates of private institutions). ${ }^{34}$ In 2017, nearly 11,000 graduates of 131 colleges and schools of pharmacy reported an average amount borrowed of $\$ 163,494$ ( $\$ 136,328$ for graduates of public institutions and $\$ 189,317$ for graduates of private institutions). ${ }^{35}$ Although more than 50,000 PharmDs graduated between 2012 and 2016 and the average student debt skyrocketed by more than $\$ 40,000$ in five years, it must be observed that BLS data indicate that pharmacist salaries have plateaued and as many as $20 \%$ may end up working in part-time positions. ${ }^{36}$

\section{Pharmacists Have Changed But Their Roles Have Not}

In December 2000, the US Department of Health \& Human Services, Health Resources and Services Administration (HRSA) Bureau of Health Professions produced a report for Congress entitled "The Pharmacist Workforce: A Study of the Supply and Demand for Pharmacists." ${ }^{37}$ This report concluded that there was an extensive shortage of trained pharmacists and made several recommendations including expanding enrollment in schools and colleges of pharmacy. Interestingly, the 2000 HRSA report mentioned a 1998 BLS finding that $60 \%$ of pharmacist positions were in retail and about $29 \%$ in health care institutions and almost 20 years later, 2016 BLS data reflect an identical distribution between the two practice settings. This report also noted that the Aggregate Demand Index (the precursor to the PDI) indicated a moderate to strong demand for pharmacists with ratings between 4 and 5 in every geographic region and projected growth of $14.5 \%$ from 196,000 in 2000 to 224,500 pharmacists by 2010 . However, this projection was almost immediately exceeded by 2002 BLS data, reporting pharmacist supply of 230,000. In 2014, HRSA's National Center for Health Workforce Analysis projected a 35\% growth in pharmacist positions between 2012 and 2025, from 264,100 to 355,300 but only a $16 \%$ increase in demand to 306,400 that would result in a substantial oversupply. ${ }^{38}$ Again the 2016 BLS data exceeded the HRSA demand projection by nine years and 6,100 jobs. Factors proposed in the report that may increase demand included expansion of the Affordable Care Act, changes in reimbursement models, and increases in clinical roles for pharmacists.

It is important to consider that the 2014 HRSA report was projecting a surplus of 48,900 pharmacists and that the HRSA 2025 projected demand number was reached by 2016 . The current trajectory indicates the potential for a much greater surplus in the next several years. It is critical to reflect on the predominant factor that is driving new supply of pharmacists: the meteoric growth in pharmacy school enrollments that is flooding the market with new PharmD graduates at a rate much faster than workforce demand. In the last 10 years, the number of pharmacy schools in the US increased 38\% from 100 to 138 ; PharmD enrollment increased $25 \%$ from 50,691 to 63,464 ; and PharmD graduates rose $48 \%$ from 9,812 to 14,556 . Over the next 10 years based on current rates, this means that $\sim 145,000$ new pharmacists would be looking to replace nearly half of the currently-practicing pharmacists. ${ }^{39}$

\section{Advocating For Change in Pharmacist Roles is Not Enough}

In 2006 several AACP committees (2005-06 Argus Commission, Academic Affairs, Professional Affairs, and Research and Graduate Affairs) produced the "Roadmap to 2015: Preparing Competent Pharmacists and Pharmacy Faculty for the Future." 40 This report anticipated changes in non-distributive pharmacy practice functions including increased patient care in private and group homes, better integration of pharmacists into the health care team, and expanded patient interaction through technological advances. The report advocated for colleges and 


\section{American Journal of Pharmaceutical Education 2019; 83 (1) Article 7051.}

schools of pharmacy to emphasize these skills in their curricula. In 2009 Jungnickel and colleagues foresaw similar competencies for pharmacists of the future and proposed significant changes to curricula to train students for future patient-focused collaborative practice. ${ }^{41}$ Accreditation standards released by the Accreditation Council for Pharmacy Education (ACPE) in 2016 reflected these forward-thinking perspectives. ${ }^{42}$

While pharmacy colleges and schools have implemented PharmD curricula that meet the ACPE Standards, the transformation of the profession to more patient-care focused jobs envisioned by academia may not have materialized at the same rate as the supply of new pharmacists. The PWC 2009 national pharmacist workforce report found that full-time pharmacists devoted $16 \%$ of their time to patient care services. In 2014, this increased to $21 \%$ overall, although one-third of retail pharmacist respondents specified that they spend "much more" time on patient care services. ${ }^{22}$ In the most recent projection for pharmacists, BLS did not anticipate substantial shifts in the two main types of practice: in 2016, retail trade positions represented $60.4 \%$ of the profession and hospital positions $24.8 \%$; by 2026 these are projected to be $59.5 \%$ and $25.0 \%$ respectively. ${ }^{30}$ Most new PharmD graduates are employed in retail pharmacy and this balance is not expected to shift; therefore, the paradigm change needs to include expansion of value-based, patientcentered pharmaceutical care in the retail settings.

In 2013 Brown worried about "looming joblessness," 43 suggesting that the surge in supply of pharmacy school graduates since 2000 may not be mitigated by increased demand expected by aging baby boomers and the Affordable Care Act. Brown issued a clarion call for all pharmacy associations to concentrate on expanding the patient care focus of ambulatory clinics into community pharmacy practice to create new and more effective pharmacist jobs in the retail area where the majority of graduates are employed. ${ }^{44}$ Knapp and Schommer issued a response to Brown, observing that not one but several sweeping changes are needed alter the trajectory of supply and demand as "tipping points." 45 They advocated for a post-graduate residency requirement for all PharmD graduates, adoption of new patient-focused business models and practice structures, updates to legislation including provider status for pharmacists, and alignment of payment policies. They also forecast an improving economy, increases in pharmacist retirements and part-time positions, and decreases in pharmacy school enrollments. In 2015 Romanelli and Tracy also recognized significant factors currently affecting the profession of pharmacy, including flattening salaries and reductions in dispensing fees, increases in automated dispensing, and the expanding need for specialty therapeutics. ${ }^{45}$ They postulated a future two-tier system of lower-paid dispensing pharmacists and higher paid and credentialed nondispensing/clinical pharmacists. This innovation would disrupt the educational system and the profession, and they cautioned the academy to prepare to adapt. But collective response to these prescient warnings and progress on these tipping points have been slow over the last five years.

Despite all of this economic data and cautionary observations by scholars, the number of pharmacy schools has swollen to 143 (132 accredited schools, seven in candidate status, and four more in pre-candidate status). ${ }^{46}$ AACP institutional research data indicated that total enrollments have grown $20 \%$ from 52,685 in 2007-2008 to 63,087 pharmacy students in 2016-2017..$^{47}$ Data over this period indicate that among schools opened prior to 2007 , PharmD enrollment peaked in 2013 and has shrunk back to pre-2009 levels; however, enrollment at the $30+$ schools opening after 2007 has skyrocketed from 1,000 to more than 10,000 enrolled students in just 10 years (Figure 1).

Colleges and schools of pharmacy remain acutely focused on building their pipeline of applicants, although the number of applications has been declining in recent years from a record high in 2010 of 111,744 applications across 119 schools (mean of 939 per school), to 72,941 applications and 140 schools in 2017 (mean of 521 per school). Economic patterns show that this is not just a pharmacy education issue; typically, post-secondary enrollments decline as job opportunities increase after an economic recession. According to the US Census Bureau, total college enrollment peaked in 2011 and has been on the decline through 2016. ${ }^{48,49}$ Despite concerted marketing efforts, pharmacy school enrollments are likely to continue this overall trend.

\section{Observe the Data and Trends of Another Professional Doctorate}

The American Bar Association is the accrediting body for law schools. The 204 accredited law schools graduated almost 35,000 students in 2017 and the national first-time bar examination pass rate for licensure was $78 \%{ }^{50}$ According to the National Association for Law Placement (NALP) that tracks trends in law school graduate employment, in 2015 fewer than $67 \%$ of law graduates were able to find employment in positions requiring bar passage ("barred" positions), and this was almost a $10 \%$ drop over the last 10 years. ${ }^{51}$ This percentage would be even worse if not for an important observation in the raw numbers: decreases in the annual number of jobs available during this time period were largely proportional to reductions in class size. ${ }^{52}$ In fact, law school 


\section{American Journal of Pharmaceutical Education 2019; 83 (1) Article 7051.}

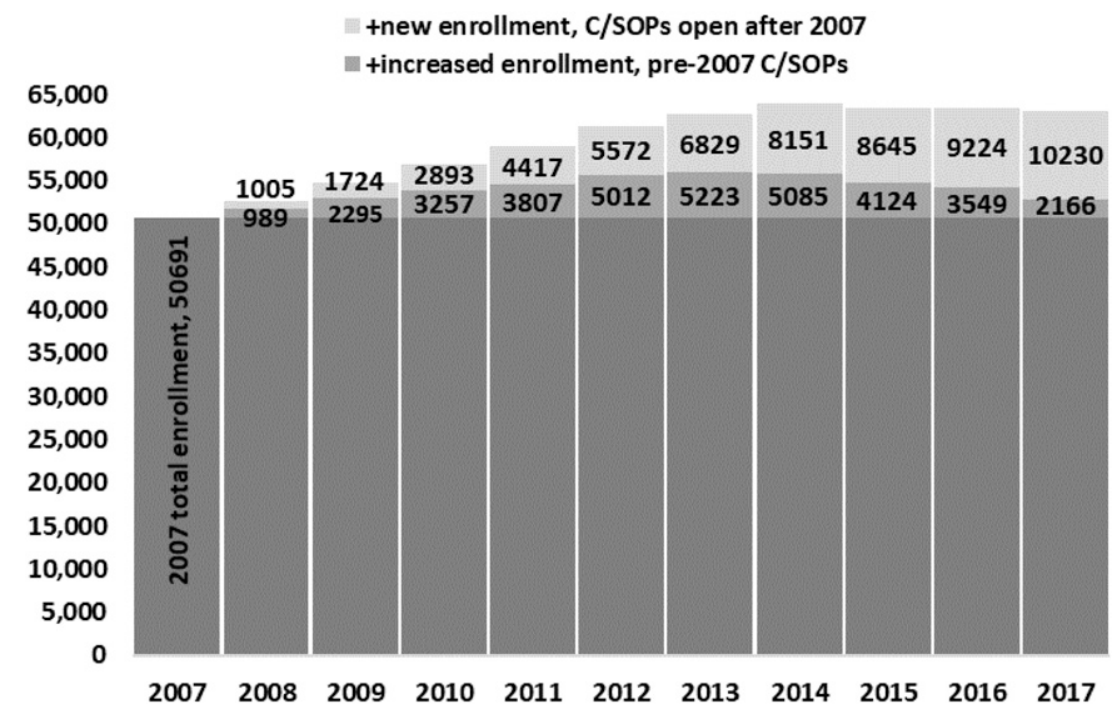

Figure 1. Comparing Enrollment Changes in New (Open After 2007) and Existing (Open Pre-2007) Pharmacy Colleges and Schools.

graduating class size in 1996 and 2015 were almost identical in number; by comparison, the number of pharmacy school graduates increased by $75 \%$ in that timeframe (from 8,003 in 1996 to 13,994 in 2015). Lastly, the salary trends for new law graduates have remained flat for almost 30 years when factoring inflation, which is a relatively new circumstance emerging in the pharmacy profession. ${ }^{53}$

\section{Creating New Roles Must Be The Highest Priority Now}

Is it the responsibility of pharmacy colleges and schools to ensure that their graduates secure full-time employment? The US Department of Education considers gainful employment to be a reportable outcome [34 CFR 668.412(a)], and the Accreditation Council for Pharmacy Education (ACPE) requires pharmacy colleges and schools to disclose it annually. ${ }^{54}$ Is it appropriate for pharmacy schools, accreditors, and associations to focus on growing pharmacy education, recruiting applicants, accepting their tuition and financial aid dollars, and preparing them for employability with career preparation programs, but not recognizing and responding to changes in workforce demand?

Pharmacy colleges and schools must take immediate action to reduce class size. At the individual school level, cutting enrollment can be politically and financially challenging; however, it must be acknowledged that the downstream costs of focusing on quantity are already being felt. These include decreased faculty morale from having to do more with less and increased workload from remediation of weak students, and negative impact on student well-being due to not meeting threshold progression indicators and increasing debt and worry. ${ }^{55}$ Lack of meaningful change at the root cause of imbalanced supply and demand contributes to faculty and student burnout, an important issue that is gaining national attention across many health care professions. ${ }^{56}$ Accreditation is the ultimate source of consumer protection for both prospective students and for the public, and the goal of accreditation is to ensure that programs meet acceptable levels of quality. ${ }^{57}$

As part of their strategic planning, pharmacy associations must focus on mechanisms to create demand for pharmacy graduates through their advocacy efforts. It is critical for associations to redirect efforts, activities, and funding to creating/building demand for graduates. The associations have the collective power to convince employers that pharmacists are of greater value to their businesses than automated dispensing. Leaders within the academy have long advocated on behalf of these highly trained pharmacy graduates for better utilization of their skills, noting the tremendous potential for increased access to care in community settings including immunizations and medication therapy management, and the value of consumer education for medication adherence and selfcare. ${ }^{58}$ Of note, AACP's Strategic Priority 3: Innovation in Education and Practice focuses on driving innovation and change in Interprofessional Education (IPE) and Interprofessional Practice (IPP). ${ }^{59}$ AACP must continue to lead and partner with other pharmacy associations to influence employers to quickly expand innovative practice models for the 63,000-plus pharmacy students who are on the cusp of entering the workforce. Associations and employers should investigate innovative business models with sponsors and angel investors who recognize the value of social entrepreneurship, to demonstrate proof of concept for new revenue streams. 


\section{American Journal of Pharmaceutical Education 2019; 83 (1) Article 7051.}

\section{Change is Coming, Hopefully}

The profession is close to gaining provider status in a bill currently before Congress: HR 592/S 109, the Pharmacy and Medically Underserved Areas Enhancement Act. ${ }^{60,61}$ The bill would provide Medicare coverage and payment for certain legally authorized pharmacist services that would otherwise be covered by Medicare if performed by a physician, in a health-professional shortage area, or a medically underserved area or population. As of January 7 , 2019, there are 296 co-sponsors in the House of Representatives (124 Democrats, 172 Republicans) and 55 in the Senate (30 Democrats, 24 Republicans, 1 Independent). The tremendous bipartisan support for this bill indicates recognition of the value of the pharmacist as a patient care provider, and its passage will make an immediate impact on the profession nationwide. This change, along with laws allowing immunizations, medication therapy management, and collaborative practice agreements, will serve as a strong foundation for the future of patient-centered pharmacy practice. The transition from fee-for-service to valuebased care should make simple business sense to employers, particularly the retail chains, and PharmD graduates are trained and ready to hit the ground running in these new practice models. Retail employers must accelerate changes in their current business model to seize upon new patient-focused revenue opportunities.

We are on the brink of transformation of the profession, but several important changes are still required to alter the current trajectories of supply and demand. Pharmacy schools, associations, and employers must devote all energies to immediate and significant actions that tip the balance in favor of pharmacists of the future.

\section{REFERENCES}

1. Hecker DE. Employment outlook: 2002-12. Occupational employment projections to 2012. BLS Monthly Labor Review, February 2004. https://www.bls.gov/opub/mlr/2004/02/art5full.pdf. Accessed February 16, 2018.

2. US Department of Labor, Bureau of Labor Statistics. Employment projections: occupational employment projections. https://www.bls.gov/ emp/ep_data_occupational_data.htm. Accessed February 16, 2018.

3. US Department of Labor, Bureau of Labor Statistics.

Occupational outlook handbook, healthcare occupations, pharmacists, job outlook. https://www.bls.gov/ooh/healthcare/ pharmacists.htm\#tab-6. Accessed February 16, 2018.

4. US Congress, Legislation, $115^{\text {th }}$ Congress, H.R.592 - Pharmacy and Medically Underserved Areas Enhancement Act. https://www. congress.gov/bill/115th-congress/house-bill/592. Accessed February 16, 2018.

5. US Department of Labor, Bureau of Labor Statistics. BLS information: about the US Bureau of Labor Statistics. https://www. bls.gov/bls/infohome.htm. Accessed February 16, 2018.

6. US Department of Labor, Bureau of Labor Statistics. Occupational employment statistics: overview. https://www.bls.gov/ oes/oes_emp.htm. Accessed February 16, 2018.
7. Richards E. Occupational employment projections to 2022. BLS Monthly Labor Review, December 2013. https:/www.bls.gov/opub/ $\mathrm{mlr} / 2013 /$ article/pdf/occupational-employment-projections-to-2022. pdf. Accessed February 16, 2018.

8. Dohm A, Shniper L. Employment outlook: 2006-16. BLS Monthly Labor Review, November 2007. https://www.bls.gov/opub/ mlr/2007/11/art5full.pdf. Accessed February 16, 2018.

9. The Center for Health Workforce Studies, School of Public Health, University at Albany, State University of New York. Health care employment projections: an analysis of Bureau of Labor Statistics settings and occupational projections, 2012-2022. May 2014. http://www.chwsny.org/wp-content/uploads/2014/08/ blsproj2014_Final_reduced.pdf. Accessed February 16, 2018. 10. US Department of Labor, Bureau of Labor Statistics.

Employment projections: projections methodology. https://www.bls. gov/emp/ep_projections_methods.htm. Accessed February 16, 2018. 11. American Association of Colleges of Pharmacy. Resources, Pharmacy Workforce Center, pharmacist demand indicator, about the transition. https://pharmacymanpower.com/about_transition.php. Accessed May 24, 2018

12. American Association of Colleges of Pharmacy. Resources, Pharmacy Workforce Center. https://www.aacp.org/resource/ pharmacy-workforce-center. Accessed February 16, 2018.

13. American Association of Colleges of Pharmacy. Resources, Pharmacy Workforce Center, pharmacist demand indicator. https:// www.aacp.org/article/pharmacist-demand-indicator. Accessed February 16, 2018.

14. American Association of Colleges of Pharmacy. Resources, Pharmacy Workforce Center, pharmacist demand indicator, About PDI. https://pharmacymanpower.com/about.php. Accessed February 16, 2018.

15. American Association of Colleges of Pharmacy. Resources, Pharmacy Workforce Center, pharmacist demand indicator, transition of the aggregate demand index (ADI) to the pharmacist demand indicator (PDI). https://www.aacp.org/sites/default/files/ transition_from_the_pharmacy_aggregate_demand_index_ information_final.pdf. Accessed February 16, 2018.

16. Kreling DH. National and Midwest workforce/job market data. Presented at the 83rd NABP/AACP District IV Meeting, November 2, 2016. https://www.district4nabp-aacp.org/wp-content/uploads/ 2017/03/Wed-Session-2-KrelingD.National-Workforce_Job-MktData.pdf. Accessed February 16, 2018.

17. American Association of Colleges of Pharmacy. Resources, pharmacy workforce center, pharmacist demand indicator, trend data. https://pharmacymanpower.com/trends.php. Accessed February 16, 2018. 18. American Association of Colleges of Pharmacy, Resources, Pharmacy Workforce Center, National Pharmacist Workforce Studies. https://www.aacp.org/article/national-pharmacistworkforce-studies. Accessed February 16, 2018.

19. American Association of Colleges of Pharmacy. Resources, pharmacy workforce center, national pharmacist workforce studies, 2000 national pharmacist workforce study. https://www.aacp.org/ article/2000-national-pharmacist-workforce-study. Accessed February 16, 2018.

20. American Association of Colleges of Pharmacy. Resources, pharmacy workforce center, national pharmacist workforce studies, 2004 national pharmacist workforce study. https://www.aacp.org/ article/2004-national-pharmacist-workforce-study. Accessed February 16, 2018.

21. American Association of Colleges of Pharmacy. Resources, pharmacy workforce center, national pharmacist workforce studies, 


\section{American Journal of Pharmaceutical Education 2019; 83 (1) Article 7051.}

2009 national pharmacist workforce study. https://www.aacp.org/ article/2009-national-pharmacist-workforce-study. Accessed February 16, 2018.

22. American Association of Colleges of Pharmacy. Resources, pharmacy workforce center, national pharmacist workforce studies, 2014 national pharmacist workforce study. https://www.aacp.org/ article/2014-national-pharmacist-workforce-study. Accessed February 16, 2018.

23. Knapp KK, Cultice JM. New pharmacist supply projections: lower separation rates and increased graduates boost supply estimates. JAPhA. 2007;47(4):463-470.

24. American Association of Colleges of Pharmacy. Resources, Resources, pharmacy workforce center, national pharmacist workforce studies, additional pharmacy workforce resources, 2014 NABP e-profile aggregate data report. https://www.aacp.org/sites/ default/files/2017_nabp_e-profile_aggregate_analysis_report.pdf. Accessed February 16, 2018.

25. National Association of Boards of Pharmacy, CPE monitor service. https://nabp.pharmacy/cpe-monitor-service/. Accessed February 16, 2018.

26. US Department of Labor, Bureau of Labor Statistics. Occupational outlook handbook, healthcare occupations. https:/www.bls.gov/ooh/ healthcare/home.htm. Accessed February 16, 2018.

27. US Department of Labor, Bureau of Labor Statistics. Occupational outlook handbook, healthcare occupations, podiatrists, job outlook. https://www.bls.gov/ooh/healthcare/podiatrists.htm. Accessed February 16, 2018

28. US Department of Labor, Bureau of Labor Statistics. Occupational outlook handbook, healthcare occupations, physicians and surgeons, job outlook. https://www.bls.gov/ooh/healthcare/ physicians-and-surgeons.htm. Accessed February 16, 2018. 29. US Department of Labor, Bureau of Labor Statistics. Occupational outlook handbook, healthcare occupations, dentists, job outlook. https://www.bls.gov/ooh/healthcare/dentists.htm. Accessed February 16, 2018.

30. US Department of Labor, Bureau of Labor Statistics. Occupational outlook handbook, healthcare occupations, pharmacists, job outlook, job prospects, employment projections data for pharmacists 2016-26, employment by industry. https://www.bls. gov/emp/ind-occ-matrix/occ_xlsx/occ_29-1051.xlsx. Accessed February 16, 2018.

31. US Department of Labor, Bureau of Labor Statistics. Occupational outlook handbook, fastest growing occupations. https:// www.bls.gov/ooh/fastest-growing.htm Accessed February 16, 2018. 32. US Department of Labor, Bureau of Labor Statistics. Occupational employment statistics. https://www.bls.gov/oes/tables. htm. Accessed February 16, 2018.

33. US Department of Labor, Bureau of Labor Statistics. Occupational outlook handbook, healthcare occupations, pharmacists, pay. https://www.bls.gov/ooh/healthcare/pharmacists. htm\#tab-5. Accessed February 16, 2018.

34. American Association of Colleges of Pharmacy. Research, institutional research, curriculum quality surveys, 2012 National Graduating Student Summary Report. https:/www.aacp.org/sites/ default/files/2017-10/2012_GSS_final\%20summary\%20report_all\% 20schools_105_with\%20charts.pdf. Accessed February 16, 2018. 35. American Association of Colleges of Pharmacy. Research, institutional research, curriculum quality surveys, 2017 National Graduating Student Summary Report. https:/www.aacp.org/sites/ default/files/2017-10/2017_GSS_National\%20Summary\%20Report. pdf. Accessed February 16, 2018.
36. American Association of Colleges of Pharmacy. Resources, Pharmacy Workforce Center, national pharmacist workforce studies, additional pharmacy workforce resources. The pharmacist workforce: a study of the supply and demand for pharmacists. https:// www.aacp.org/sites/default/files/pharmacists_workforce.pdf. Accessed February 16, 2018.

37. Report to Congress. The Pharmacist Workforce: A Study of the Supply and Demand for Pharmacists. Department of Health \& Human Services Health Resources and Services Administration Bureau of Health Professions, December 2000. https://www.ihrp.uic. edu/files/Pharmacists\%20Workforce.pdf. Accessed February 16, 2018.

38. Health Resources \& Services Administration, National Center for Health Workforce Analysis, Health Workforce Projections: Pharmacists (2014). https://bhw.hrsa.gov/sites/default/files/bhw/ nchwa/projections/pharmacists.pdf. Accessed February 16, 2018. 39. American Association of Colleges of Pharmacy. Research, institutional research, student applications, enrollments and degrees conferred reports. https://www.aacp.org/research/institutionalresearch/student-applications-enrollments-and-degrees-conferred. 40. Roche VF, Nahata MC, Wells BG, Kerr RA, Draugalis JR, Maine LL. Roadmap to 2015: preparing competent pharmacists and pharmacy faculty for the future. Combined report of the 2005-06 Argus Commission and the academic affairs, professional affairs, and research and graduate affairs committees. Am J Pharm Educ. 2006; 70(5):Article S5.

41. Jungnickel PW, Kelley KW, Hammer DP, Haines ST, Marlowe KF. AACP curricular change summit supplement. Addressing competencies for the future in the professional curriculum. Am J Pharm Educ. 2009;73(8):Article 156.

42. Accreditation Council for Pharmacy Education. PharmD program accreditation. https://www.acpe-accredit.org/pharmdprogram-accreditation/. Accessed February 16, 2018.

43. Brown DL. A looming joblessness crisis for new pharmacy graduates and the implications it holds for the academy. Am J Pharm Educ. 2013;77(5):Article 90.

44. Knapp KK, Schommer JC. Finding a path through times of change. Am J Pharm Educ. 2013;77(5):Article 91.

45. Romanelli F, Tracy TS. Viewpoint: a coming disruption in pharmacy? Am J Pharm Educ. 2015;79(1):Article 1.

46. Accreditation Council for Pharmacy Education. Memories and milestones - recognizing ACPE's $85^{\text {th }}$ anniversary. https://www. acpe-accredit.org/pdf/ACPE_Update\%20Fall2017.pdf. Accessed February 16, 2018.

47. American Association of Colleges of Pharmacy. Institutional research. 2017 profile of pharmacy students. https://www.aacp.org/ research/institutional-research. Accessed May 24, 2018.

48. Schmidt EP. College enrollment before, during and after the great recession. Working Paper No. SEHSD-WP2017-29. US Census Bureau, Census working papers, 2017. https://www.census.gov/ library/working-papers/2017/demo/SEHSD-WP2017-29.html. Accessed February 16, 2018.

49. US Census Bureau, CPS historical time series, tables on school enrollment, August 23, 2017. https://www.census.gov/data/tables/ time-series/demo/school-enrollment/cps-historical-time-series.html. Accessed February 16, 2018.

50. American Bar Association. Statistics. https://www.americanbar. org/groups/legal_education/resources/statistics.html. Accessed May 24, 2018.

51. Employment rate of new law grads unchanged as both the number of graduates and the number of jobs found decline. NALP 


\section{American Journal of Pharmaceutical Education 2019; 83 (1) Article 7051.}

Bulletin, October 2016. https://www.nalp.org/1016research. Accessed May 24, 2018.

52. The stories behind the numbers: jobs for new grads over more than two decades. NALP Bulletin, December 2016. https://www. nalp.org/1216research. Accessed May 24, 2018.

53. Salary trends for new law graduates $-1985-2013$. NALP Bulletin, January 2015. https://www.nalp.org/0115research. Accessed May 24, 2018.

54. Accreditation Council for Pharmacy Education. Policies and procedures for ACPE accreditation of professional degree programs January 2018. https://www.acpe-accredit.org/pdf/PoliciesandProcedures. pdf. Accessed May 24, 2018.

55. The law-school scam. https://www.theatlantic.com/magazine/ archive/2014/09/the-law-school-scam/375069/. Accessed May 24, 2018. 56. National Academy of Medicine. 2017 action collaborative on clinician well-being and resilience. https://nam.edu/initiatives/clinicianresilience-and-well-being/\#noodle. Accessed May 24, 2018.
57. US Department of Education. Glossary. https://ope.ed.gov/ accreditation/Glossary.aspx. Accessed May 24, 2018.

58. Maine L. Pharmacists take their place on the care team. Health Progress. March-April 2018. https://www.chausa.org/docs/defaultsource/health-progress/pharmacists-take-their-place-on-the-careteam.pdf?sfvrsn=2. Accessed March 9, 2018.

59. American Association of Colleges of Pharmacy. Strategic plan of AACP. https://www.aacp.org/article/strategic-plan-aacp. Accessed May 24, 2018.

60. US Congress, Legislation, $115^{\text {th }}$ Congress, H.R.592 - Pharmacy and Medically Underserved Areas Enhancement Act, Cosponsors. https://www.congress.gov/bill/115th-congress/house-bill/592/ cosponsors. Accessed January 7, 2019.

61. US Congress, Legislation, $115^{\text {th }}$ Congress, S. 109 - Pharmacy and Medically Underserved Areas Enhancement Act, Cosponsors. https://www.congress.gov/bill/115th-congress/senate-bill/109/ cosponsors. Accessed January 7, 2019. 